\title{
Filtering out parasites: Sand crabs (Lepidopa benedicti) are infected by more parasites than sympatric mole crabs (Emerita benedicti)
}

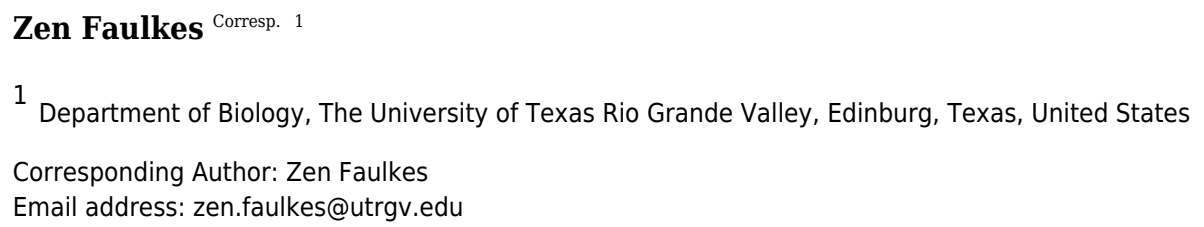

Two digging decapod crustaceans, the sand crab species Lepidopa benedicti and the mole crab species Emerita benedicti, both live in the swash zone of fine sand beaches. They were examined for two parasites that infect decapod crustaceans in the region, an unidentified nematode previously shown to infect $L$. benedicti, and cestode tapeworm larvae, Polypocephalus sp., previously shown to infect shrimp (Litopenaeus setiferus). Lepidopa benedicti were almost always infected with both parasite species, while $E$. benedicti were rarely infected with either parasite species. This difference in infection pattern suggests that tapeworms are ingested during sediment feeding in $L$. benedicti, which $E$. benedicti avoid by filter feeding. Larger $L$. benedicti had more Polypocephalus sp. larvae. The thoracic ganglia, which make up the largest proportion of neural tissue, contained the largest numbers of Polypocephalus sp. larvae. Intensity of Polypocephalus sp. infection was not correlated with how long $L$. benedicti remained above sand in behavioural tests, suggesting that Polypocephalus sp. do not manipulate the sand crabs in a way that facilitates trophic transmission of the parasite. L. setiferus may be a primary host for Polypocephalus sp., and L. benedict may be a secondary, auxiliary host. 
1 Filtering out parasites: Sand crabs (Lepidopa benedicti) are infected by more parasites

2 than sympatric mole crabs (Emerita benedicti)

3

4 Zen Faulkes ${ }^{1}$

51 Department of Biology, The University of Texas Rio Grande Valley, 1201 W. University 6 Drive, Edinburg, TX 78539, U.S.A.

7

8 Correspondence to: Zen Faulkes, Department of Biology, The University of Texas Rio 9 Grande Valley, 1201 W. University Drive, Edinburg, TX 78539, U.S.A. Phone 956-66510 2614. Fax 956-665-3657. Email zen.faulkes@utrgv.edu. 
12 Two digging decapod crustaceans, the sand crab species Lepidopa benedicti and the

13 mole crab species Emerita benedicti, both live in the swash zone of fine sand beaches.

14 They were examined for two parasites that infect decapod crustaceans in the region, an

15 unidentified nematode previously shown to infect $L$. benedicti, and cestode tapeworm

16 larvae, Polypocephalus sp., previously shown to infect shrimp (Litopenaeus setiferus).

17 Lepidopa benedicti were almost always infected with both parasite species, while $E$.

18 benedicti were rarely infected with either parasite species. This difference in infection

19 pattern suggests that tapeworms are ingested during sediment feeding in L. benedicti,

20 which E. benedicti avoid by filter feeding. Larger L. benedicti had more Polypocephalus

21 sp. larvae. The thoracic ganglia, which make up the largest proportion of neural tissue,

22 contained the largest numbers of Polypocephalus sp. larvae. Intensity of

23 Polypocephalus sp. infection was not correlated with how long L. benedicti remained

24 above sand in behavioural tests, suggesting that Polypocephalus sp. do not manipulate

25 the sand crabs in a way that facilitates trophic transmission of the parasite. L. setiferus

26 may be a primary host for Polypocephalus sp., and L. benedict may be a secondary,

27 auxiliary host.

\section{INTRODUCTION}

Parasites can be generalists that infect many host species, or specialists that infect only a small number of host species, or even just one host species. (Poulin 2007;

31 Schmid-Hempel 2011; Loker \& Hofkin 2015). A benefit of being a specialist may be 32 increased adaptation to a host species. Specialization should be favoured in 
33 endoparasites that manipulate host behaviour (Adamson \& Caira 2011; Fredensborg 34 2014), because the nervous systems generating behaviour are probably anatomically 35 and physiologically more variable than other types of tissue (Bullock 1993; Bullock 36 2004; Bullock 2006). Behavioural manipulation often manifests as parasite induced 37 tropic transmission (PITT), in which parasites with multiple host life cycles change the 38 behaviour of one host in such a way as to enhance the likelihood of the host being 39 40 eaten by a predatory species that is the next host in the parasite's life cycle (Moore 2002; Lafferty \& Shaw 2013) Sand crabs (Lepidopa benedicti) and mole crabs (Emerita benedicti) are digging

42 anomuran crustaceans in the same superfamily (Hippoidea) (Figure 1), which are both 43 found in the swash zones of sandy beaches in the Gulf of Mexico. Given that they are 44 relatively closely related and found in the same habitat, it is a reasonable hypothesis 45 that they might have similar parasites to each other. Lepidopa benedicti is often infected 46 by an unidentified nematode species that does not appear to manipulate host behaviour 47 (Joseph \& Faulkes 2014), which might also infect E. benedicti. Other parasites that infect decapod crustaceans where these two species live are larval cestode tapeworms in the genus Polypocephalus, which infect white shrimp 50 (Litopenaeus setiferus) (Carreon, Faulkes \& Fredensborg 2011; Carreon \& Faulkes 51 2014). Although the life cycle of species in this genus is not completely worked out, it 52 seems likely that it has a two part life cycle (Figure 2): crustaceans (Villella, Iversen \& 53 Sindermann 1970; Owens 1985; Shields 1992; Hudson \& Lester 1994; Brockerhoff \& 54 Jones 1995; Payne 2010) and other invertebrates (Cake 1979) for the larval stage, and 55 elasmobranch fishes (e.g., skates and rays) as the definitive hosts for adults (Butler 
56 1987; Call 2007; Koch 2009). There are reasons that could suggest Polypocephalus

57 spp. could be either generalists or specialists. On the one hand, Polypocephalus spp.

58 larvae infect multiple species from at least two phyla (Cake 1979; Owens 1985;

59 Brockerhoff \& Jones 1995), suggesting that species in this genus are generalists. On

60 the other hand, Polypocephalus sp. inhabit the nervous system of crustaceans, and

61 appear to manipulate behaviour in L. setiferus (Carreon, Faulkes \& Fredensborg 2011),

62 which are factors that suggest species in this genus are specialists.

63 Polypocephalus sp. is also a candidate for studying the manipulation of host

64 behaviour, because the larval stage infects the neural tissue of their decapod

65 crustacean hosts. Being in or near the nervous system would seem to make such

66 manipulation easier for parasites. In white shrimp, increased infection was correlated

67 with increased activity of the host (Carreon, Faulkes \& Fredensborg 2011), which was

68 hypothesized to be a case of parasite-induced trophic transmission. A trophically

69 transmitted parasite in a digging crustacean might be excepted to change the behaviour

70 of its host so it spends more time above sand (Joseph \& Faulkes 2014). Litopenaeus

71 setiferus do dig into sand (Eldred et al. 1961; Fuss 1964; Pinn \& Ansell 1993), and their

72 increased activity with infection would be consistent with the prediction above.

73 This paper compares the patterns of infection in L. benedicti and E. benedicti for

74 both nematode and cestode parasites, and tests whether Polypocephalus sp.

75 manipulates the behaviour of $L$. benedicti as they do with shrimp (Carreon, Faulkes \&

76 Fredensborg 2011). 


\section{METHODS} collected from the beaches of South Padre Island, Texas by turning over sand with a

80 shovel near, and parallel to, the waterline of the shore (Faulkes, in press; Murph \&

81 Faulkes 2013). Crabs found in the overturned sand or in the water of the trench created were collected. Individuals were sexed by examining pleopod size (longer in females) and the carapace length was measured with digital calipers. Different individuals were used to study infection by nematodes and Polypocephalus sp.To examine infection of nematodes, E. benedicti were broken using forceps, and nematodes found in the dissecting dish were counted, following the previous study on L. benedicti (Joseph \&

87 Faulkes 2014). To examine infection of Polypocephalus sp., individuals were anaesthetised by chilling for $\sim 20$ minutes on crushed ice, dissected in sea water, and the nerve cord was removed. The nerve cord was cut into smaller sections, which were pinned in dishes lined with Sylgard (Dow Corning). The nerve cords were dehydrated in

91 a progressive ethanol series ( $70 \%$ ethanol for 5 minutes, $90 \%$ ethanol for 5 minutes,

$92100 \%$ ethanol for 5 minutes, then $100 \%$ ethanol again for 10 minutes), cleared in methyl

93 salicylate on a depression slide, viewed under a compound microscope (Olympus CX41), and photographed (Olympus C-5050 Zoom digital camera), following a previous study of L. setiferus (Carreon \& Faulkes 2014). In some cases, consecutive images at different focal points in the $Z$ axis were compiled into a single image using Helicon

97 Focus v. 6.7.1 Lite (Helicon Soft Ltd.). Initial observations of 10 individuals of each species indicated that variation in numbers of parasites infecting $L$. benedicti was sufficient to test whether there was a 
100 correlation between infection and host behaviour. Because few E. benedicti were

101 infected, and there was very little variation in the number of parasites of those that were

102 infected, their behaviour was not examined.

103 Behavioural tests were similar to those described in Joseph \& Faulkes (2014).

104 Individuals were video-recorded digging in a tank $300 \mathrm{~mm}$ wide $\times 150 \mathrm{~mm}$ deep $\times 200$

$105 \mathrm{~mm}$ high, filled with $\sim 75 \mathrm{~mm}$ of sand from South Padre Island covered by $\sim 75 \mathrm{~mm}$ of

106 seawater. Video was recorded with an iPad 3 using Coach My Video v. 4.4

107 (http://www.coachmyvideo.mobi). Individuals were released at the top of the tank, and

108 was filmed until the carapace was covered by sand. The total time was calculated by

109 subtracting the submergence times from release time (rounded down to whole

110 seconds). Individuals made three digging trials, each separated by a 5 minute rest

111 period when the animal was not disturbed to minimize habituation. The average of the

112 three trials was used for analysis.

113 The behaviour of crabs fell into three basic categories. An individual could (1)

114 immediately dig into sand ("direct"), (2) stay above sand by tailflipping and rowing its

115 legs (Faulkes \& Paul 1997) before digging ("swim"), or; (3) remain on the top of the

116 sand, immobile, before digging ("sit"). "Swim" and "sit" are not mutually exclusive. An

117 individual could do both in one trial, in either order. For simplicity of analyses,

118 individuals that both swam and "sat" in their three trials were omitted from analyses that 119 examined individuals.

120 Descriptive statistical analyses and graphs were made in Origin 2017 (OriginLab

121 Corporation). Nonparametric tests were used for most analyses because of 
122 nonhomogenous variation in data distribution. Nonparametric statistical analyses were

123 performed in SPSS v. 23 (IBM).

124

\section{RESULTS}

125

The previously reported prevalence of nematodes in L. benedicti $(87.0 \%, \mathrm{n}=46)$

126

(Joseph \& Faulkes 2014) was higher than in E. benedicti $(0.0 \%, n=22)$ (Figure 3A).

127 Similarly, the prevalence of Polypocephalus sp. infection in Lepidopa benedicti (98.0\%,

$128 \mathrm{n}=50)$ was higher than in E. benedicti $(18.2 \%, n=22)$ (Figure 3B). The mean intensity

129 of Polypocephalus sp. infection (Figures 3B, 4) was significantly greater in L. benedicti

130 (range $=1-170$, mean $=34.5, \mathrm{SD}=33.0, \mathrm{n}=49 ;$ uninfected animals excluded $)$ than $E$.

131 benedicti (range $=1-3$, mean $=1.5, \mathrm{SD}=1.0, \mathrm{n}=4$; uninfected animals excluded).

132 These differences are not because of the overall size of individuals examined: the

133 average size of $L$. benedicti was smaller than E. benedicti (Table 1 ) in both cases.

134 Because there were so few parasites of either species in E. benedicti, all further

135 analyses concern only L. benedicti.

136

Polypocephalus sp. larvae were closely associated specifically with neural tissue,

137 including peripheral nerves to appendages (Figure 4). The larvae often appeared on the

138 surface of ganglia and could sometimes be seen on the dissected nerve cord using a

139 stereomicroscope.

140 There is a significant correlation (Spearman's $\rho=0.49, p=0.002, n=38$ )

141 between L. benedicti size and mean intensity of Polypocephalus sp. infection (Figure 5).

142 Like other anomurans, L. benedicti have shorter abdomens than familiar

143 decapods like shrimp and crayfish. Because L. benedicti are specialized for digging and

144 swimming with thoracic legs 1 through 4 , the legs are proportionately more robust. 
145 Thoracic leg 5 is very small and used for grooming. These anatomical features are

146 reflected in the relative sizes of the ganglia in $L$. benedicti compared to other decapod

147 crustaceans. The thoracic ganglia associated with thoracic legs 1-4 are substantially

148 larger than abdominal ganglia 2-6. The fourth and fifth thoracic ganglia and the first

149 abdominal ganglion are fused. The number of larvae in the ganglia differed significantly

150 across the nervous system (Kruskal Wallis $=16.71, \mathrm{df}=6, \mathrm{p}=0.01$ ), with thoracic

151 ganglia containing the most larvae, particularly in highly infected individuals (Figure 6).

152 Contrary to the prediction that more heavily infected animals would spend more

153 time above sand, the mean intensity of Polypocephalus sp. infection was not

154 significantly correlated (Spearman's $\rho=-0.233, \mathrm{p}=0.16, \mathrm{n}=38$ ) with mean digging

155 time (Figure 7). Size of $L$. benedicti was not significantly correlated (Spearman's $\rho=-$

$1560.279, p=0.09, n=38$ ) with mean digging time (Figure 8), confirming previous findings

157 (Joseph \& Faulkes 2014).

158 The three main behaviours of $L$. benedicti (directly digging into sand, swimming,

159 or remaining stationary, or "sitting") were significantly different (Kruskal-Wallis $=70.76$,

$160 \mathrm{df}=2, \mathrm{p}<0.01$ ) in how long individuals remained above sand (Figure 9). Swimming

161 above sand and remaining stationary on top of it did not differ significantly in the

162 duration of exposure for sand crabs, although "sitting" times had greater variation,

163 resulted in the longest times that sand crabs were exposed.

164 Individuals showing different behaviour patterns had significantly different mean

165 intensities of infection (Kruskal Wallis $=8.72, \mathrm{df}=2, \mathrm{p}=0.013$ ): animals that "sat" at

166 least once had lower infection intensities than those that swam at least once or always

167 dug directly into sand (Figure 10). 


\section{DISCUSSION}

169

Two parasite species, an unidentified nematode (Joseph \& Faulkes 2014) and

170

Polypocephalus sp., infect Lepidopa benedicti with much higher prevalence and

171 intensity than in Emerita benedicti. In the case of Polypocephalus sp., a high prevalence

172 and intensity also occurs in white shrimp (L. setiferus) which also dig into sand (Eldred

173 et al. 1961; Fuss 1964; Pinn \& Ansell 1993). What distinguishes $E$. benedicti from both

174 L. benedicti and $L$. setiferus is the feeding mode. Emerita species are filter feeders

175 (Efford 1966), which L. benedicti and L. setiferus are not. Lepidopa species are

176 probably sediment feeders (Boyko 2002). This suggests that ingestion is a common

177 route of Polypocephalus sp. infection for $L$. benedicti and $L$. setiferus. Presumably, $E$.

178 benedicti avoid infection because they are filtering food from the water column, which is

179 hypothesized to have extremely low numbers of Polypocephalus sp. cysts compared to

180 sand and other surfaces

181

The lack of parasites in $E$. benedicti in this population is unusual not only

182 because the sympatric $L$. benedicti is infected, but because other populations of Emerita

183 species are infected with other parasites (Smith 2007; Oliva et al. 2008; Kolluru et al.

184 2011; Violante-Gonzalez et al. 2015; Violante-González et al. 2016). Because this study

185 did not run an entire year, however, it is possible that $E$. benedicti infections vary

186

seasonally or spatially, and that this species is heavily infected at other times or places.

187 That this study did not address whether there any substantial variation in infection rates

188 over time means that the differences in nematode infection in $L$. benedicti and $E$.

189 benedicti should be interpreted with cautiously, because the data for $L$. benedicti

190 (Joseph \& Faulkes 2014) was collected before the data for E. benedicti (this study). 
In L. setiferus, the greatest number of Polypocephalus sp. larvae is in the

192 abdominal ganglia (Carreon, Faulkes \& Fredensborg 2011), but in L. benedicti, the

193 greatest number is in the thoracic ganglia. This probably reflects which region has the

194 proportionately greater mass of neural tissue available in the two species, although

neural mass does not entirely explain distribution patterns across the nervous system

(Carreon \& Faulkes 2014). Another difference is that in L. setiferus, Polypocephalus sp.

larvae appeared to be more deeply embedded in neural tissue and were rarely visible

under a dissecting microscope until the nerve cord was either squashed or cleared. In $L$.

benedicti, larvae were in comparatively superficial positions, and could be seen with

dissecting microscopes. There also appeared to be less variation in Polypocephalus sp.

201 larval size in $L$. setiferus than $L$. benedicti (compare Figure 4 here to Figure 1 in

202 Carreon, Faulkes \& Fredensborg 2011).

203

Polypocephalus sp. does not seem to manipulate L. benedicti in a way that would

204 facilitate trophic transmission. Intuitively, one would predict that if Polypocephalus sp.

205

were manipulating sand crabs to make them vulnerable to predators, animals with more

Polypocephalus sp. would be more likely to swim or remain immobile on the top of the

sand. In anything, the evidence points towards more heavily infected individuals being

more likely to dig into sand immediately. Nevertheless, this result can be viewed as

209

consistent with the results in L. setiferus, where higher levels of infection increased

210 activity (Carreon, Faulkes \& Fredensborg 2011). Digging directly into sand and

211 swimming could both be considered higher activity by L. benedicti.

212 The apparent difference in parasite-induced behavioural manipulation in $L$.

213 setiferus and $L$. benedicti has several potential explanations. First, the Polypocephalus 
214 species infecting $L$. setiferus may not be the same species as the one infecting $L$.

215 benedicti. Although both dig in sand, there are differences in the life history of the two

216 hosts. For example, L. setiferus transition from living seagrass beds (Zimmerman \&

217 Minello 1984) to deeper water as they grow, and change preferences for salinity over

218 their lives (Williams 1984), whereas L. benedicti settle into sand after metamorphosing

219 from a pelagic larva and remain there for their entire lives (Stuck \& Truesdale 1986).

220 These differences in the niches of the host species could be consistent with there being 221 multiple Polypocephalus species. Genetic testing will eventually be able to determine if

222 there is one cestode species or multiple species. Second, L. setiferus may be the 223 preferred primary host for Polypocephalus sp. (perhaps along with other shrimp

224 species), and $L$. benedicti is a non-preferred auxiliary host. The intensity of

225 Polypocephalus sp. larvae in L. setiferus (mean = 97.7, SD = 102.6; maximum 397; $\mathrm{n}=$ 226 53; Carreon, Faulkes \& Fredensborg 2011) is approximately triple that of $L$. benedicti 227 (mean $=34.5, \mathrm{SD}=33.0 ;$ maximum 170; $\mathrm{n}=49 ;$ this study). Litopenaeus setiferus may 228 be more abundant than $L$. benedicti. Litopenaeus setiferus is commercially fished, and 229 annual catches from trawling in the Texas waters of Gulf of Mexico average 7 million 230 pounds per year (Texas Parks and Wildlife 2002). In contrast, $10 \mathrm{~m}$ transects of beach 231 often yield less than 10 L. benedicti individuals (Faulkes, in press; Murph \& Faulkes 232 2013). L. benedicti populations have only been sampled in the swash zone (Faulkes, in 233 press; Faulkes 2014) and its abundance in deeper waters is unknown (it has been 234 recorded up to $60 \mathrm{~m}$ depth; Boyko 2002). Nevertheless, it seems plausible that the 235 biomass for L. benedicti, and thus its potential as host for Polypocephalus sp., is lower 
236 than L. setiferus. Thus, there may be greater selection pressure for Polypocephalus sp.

237 to manipulate its primary host but not secondary ones.

\section{ACKNOWLEDGEMENTS}

239 Meera Joseph contributed data for Emerita benedicti nematode infection.

240

\section{LITERATURE CITED}

242

243 Adamson ML, Caira JN. 2011. Evolutionary factors influencing the nature of parasite 244 specificity. Parasitology 109: S85-S95.

Boyko CB. 2002. A worldwide revision of the recent and fossil sand crabs of the Albuneidae Stimpson and Blepharipodidae, new family (Crustacea, Decapoda, Anomura, Hippoidea). Bulletin of the American Museum of Natural History 272: 1-396.

Brockerhoff A, Jones MK. 1995. Ultrastructure of the scolex and tentacles of the metacestode of Polypocephalus species (Cestoda: Lecanicephalidae) from the blueswimmer crab Portunus pelagicus. International Journal for Parasitology 25: 1077-1088.

Bullock TH. 1993. How are more complex brains different? One view and an agenda for comparative neurobiology. Brain, Behavior and Evolution 41: 88-96.

Bullock TH. 2004. Neuroethology has pregnant agendas. Journal of Comparative Physiology A: Neuroethology, Sensory, Neural, and Behavioral Physiology 185: 291-295. 
258 Bullock TH. 2006. How do brains evolve complexity? An essay. International Journal of 259 Psychophysiology 60: 106-109.

260 Butler S. 1987. Taxonomy of some tetraphyllidean cestodes from elasmobranch fishes. $261 \quad$ Australian Journal of Zoology 35: 343-371.

262 Cake EW, Jr. 1979. Polypocephalus sp. (Cestoda: Lecanicephalidea): a description of 263 tentaculoplerocercoids from bay scallops of the northeastern Gulf of Mexico. Proceeding of the Helminthological Society of Washington 46: 165-170.

Call G. 2007. A survey of the tapeworm fauna of the cownose ray, Rhinoptera bonasus, from the northern Gulf of Mexico with comments on intermediate hosts. Ecology \& Evolutionary Biology. University of Kansas: Lawrence. M.A.: 141. http://hdl.handle.net/1808/5536

269

Carreon N, Faulkes Z. 2014. Position of larval tapeworms, Polypocephalus sp., in the ganglia of shrimp, Litopenaeus setiferus. Integrative and Comparative Biology 54: $143-148$.

272 Carreon N, Faulkes Z, Fredensborg BL. 2011. Polypocephalus sp. infects the nervous system and increases activity of commercially harvested white shrimp (Litopenaeus setiferus). Journal of Parasitology 97: 755-759.

275 Efford IE. 1966. Feeding in the sand crab, Emerita analoga (Stimpson) (Decapoda, 276 Anomura). Crustaceana 10: 167-182.

277 Eldred B, Ingle RM, Woodburn KD, Hutton RF, Jones H. 1961. Biological observations 278 on the commercial shrimp Penaeus duorarum Burkenroad, in Florida waters. Florida State Board of Conservation Professional Papers Series 3: 1-139. 
280 Faulkes Z. The phenology of sand crabs, Lepidopa benedicti (Decapoda: Albuneidae). $281 \quad$ Journal of Coastal Research. in press.

282 Faulkes Z. 2014. Abundance and size of sand crabs (Lepidopa benedicti) on South 283 Padre Island, Texas. In: Z Faulkes, ed.: figshare. http://dx.doi.org/10.6084/m9.figshare.1057959. Access date.

285 Faulkes Z, Paul DH. 1997. Coordination between the legs and tail during digging and 286 swimming in sand crabs. Journal of Comparative Physiology A 180: 161-169.

287 Fredensborg BL. 2014. Predictors of host specificity among behavior-manipulating 288 parasites. Integrative and Comparative Biology 54: 149-158.

289 Fuss CM, Jr. 1964. Observations on burrowing behavior of the pink shrimp, Penaeus duorarum Burkenroad. Bulletin of Marine Science, Gulf and Caribbean 14: 62-73.

291 Hudson DA, Lester RJG. 1994. Parasites and symbionts of wild mud crabs Scylla 292 293 serrata (Forskal) of potential significance in aquaculture. Aquaculture 120: 183199.

Joseph M, Faulkes Z. 2014. Nematodes infect, but do not manipulate digging by, sand 296 crabs, Lepidopa benedicti. Integrative and Comparative Biology 54: 101-107.

Koch KR. 2009. The lecanicephalidean fauna of three species of eagle rays of the genus Aetomylaeus (Myliobatiformes: Myliobatidae) Department of Ecology and Evolutionary Biology. University of Kansas: Lawrence. Master's: 89. http://search.proquest.com/docview/304910071

Kolluru GR, Green ZS, Vredevoe LK, Kuzma MR, Ramadan SN, Zosky MR. 2011. Parasite infection and sand coarseness increase sand crab (Emerita analoga) burrowing time. Behavioural Processes 88: 184-191. 
303 Lafferty KD, Shaw JC. 2013. Comparing mechanisms of host manipulation across host 304 and parasite taxa. The Journal of Experimental Biology 216: 56-66.

305 Loker ES, Hofkin BV. 2015. Parasitology: A Conceptual Approach. New York: Garland $306 \quad$ Science.

307 Moore J. 2002. Parasites and the behavior of animals. Oxford: Oxford University Press. 308 Murph JH, Faulkes Z. 2013. Abundance and size of sand crabs, Lepidopa benedicti 309 (Decapoda: Albuneidae), in South Texas. The Southwestern Naturalist 58: 431434.

311 Oliva ME, Barrios I, Thatje S, Laudien J. 2008. Changes in prevalence and intensity of infection of Profilicollis altmani (Perry, 1942) cystacanth (Acanthocephala) parasitizing the mole crab Emerita analoga (Stimpson, 1857): an El Niño cascade effect? Helgoland Marine Research 62: S57-S62.

Owens L. 1985. Polypocephalus sp. (Cestoda : Lecanicephalidae) as a biological marker for banana prawns, Penaeus merguiensis de Man, in the Gulf of Carpentaria. Australian Journal of Marine and Freshwater Research 36: 291-299.

Payne JT. 2010. Molecular identification of metacestodes infecting bait shrimp in the Gulf of Mexico. Biology. Tennessee Technological University: Cookeville. M.S.: 60. http://proquest.umi.com/pqdlink?did=2142187211\&Fmt=7\&clientld=12926\&RQT $=309 \& \mathrm{VName}=\mathrm{PQD}$

Pinn EH, Ansell AD. 1993. The effect of particle size on the burying ability of the brown shrimp Crangon crangon. Journal of the Marine Biological Association of the UK 73: $365-377$ 
326 Poulin R. 2007. Evolutionary ecology of parasites. Princeton, New Jersey: Princeton $327 \quad$ University Press.

328 Schmid-Hempel P. 2011. Evolutionary Parasitology: The Integrated Study of Infections, 329 Immunology, Ecology, and Genetics. Oxford: Oxford University Press.

330 Shields JD. 1992. Parasites and symbionts of the crab Portunus pelagicus from Moreton Bay, Eastern Australia. Journal of Crustacean Biology 12: 94-100.

Smith NF. 2007. Associations between shorebird abundance and parasites in the sand crab, Emerita analoga, along the California coast. Journal of Parasitology 93: 265-273.

Stuck KC, Truesdale FM. 1986. Larval and early postlarval development of Lepidopa benedicti Schmitt, 1935 (Anomura: Albuneidae) reared in the laboratory. Journal of Crustacean Biology 6: 89-110.

338 Texas Parks and Wildlife. 2002. Executive Smmary: The Texas Shrimp Fishery: A 339 report to the Governor and the 77th Legislature of Texas. TPa Wildlife. Texas Parks and Wildlife: Austin, Texas. http://tpwd.texas.gov/publications/pwdpubs/media/pwd_rp_v3400_857.pdf

342 Villella JB, Iversen ES, Sindermann CJ. 1970. Comparison of the parasites of pondreared and wild pink shrimp (Penaeus duorarum Burkenroad) in South Florida. Transactions of the American Fisheries Society 99: 789-794.

Violante-González J, Monks S, Quiterio-Rendon G, García-lbáñez S, Larumbe-Morán E, Rojas-Herrera AA. 2016. Life on the beach for a sand crab (Emerita rathbunae) (Decapoda, Hippidae): parasite-induced mortality of females in 
populations of the Pacific sand crab caused by Microphallus nicolli (Microphallidae). Zoosystematics and Evolution 92: 153-161.

350 Violante-Gonzalez J, Quiterio-Rendon G, Monks S, García-lbañez S, Pulido-Flores G,

Rojas-Herrera A, Larumbe-Moran E. 2015. Parasite communities of the Pacific mole crab, Emerita rathbunae (Anomura: Hippidae), in sandy beaches from Guerrero and Michoacán, Mexico. Open Journal of Marine Science 5: 468-476.

354 Williams AB. 1984. Shrimps, lobsters, and crabs of the Atlantic coast of the eastern United States, Maine to Florida. Washington, DC: Smithsonian Institution Press.

356 Zimmerman RJ, Minello TJ. 1984. Densities of Penaeus aztecus, Penaeus setiferus, and other natant macrofauna in a Texas salt marsh. Estuaries 7: 421-433. 


\section{Table 1 (on next page)}

Size of animals used in study. 
1 Table 1. Size of animals used in study.

Lepidopa benedicti Emerita benedicti

\begin{tabular}{lllllll}
\hline Parasite & Mean carapace length & SD & $\mathrm{n}$ & Mean carapace length & SD & $\mathrm{n}$ \\
Nematode sp. & $11.44 \mathrm{~mm}$ & 2.83 & 46 & $13.44 \mathrm{~mm}$ & 5.45 & 22 \\
& & 1.72 & 49 & $18.19 \mathrm{~mm}$ & 3.65 & 21
\end{tabular}

2 
Figure 1

Digging crab species.

A) Lepidopa benedicti. B) Emerita benedicti.
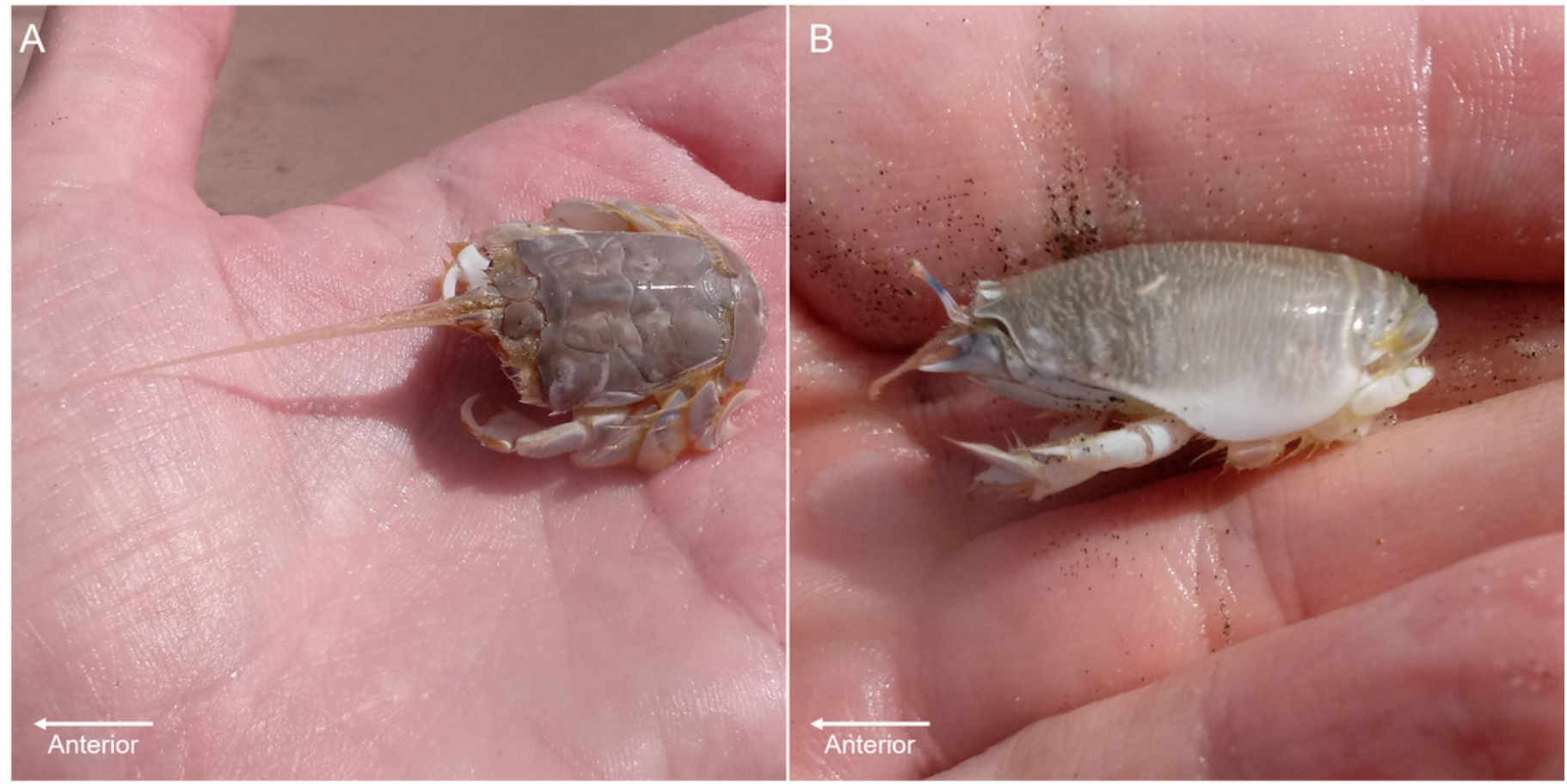


\section{Figure 2}

Hypothesized life cycle of Polypocephalus sp.

Larval stages of cestode tapeworms in the genus Polypocephalus infect crustaceans and other invertebrates. These intermediate hosts are presumably ingested by the putative definitive hosts, skates and rays, which are expected to excrete Polypocephalus eggs. Images from the Noun Project (https://thenounproject.com): shrimp by Jeffrey Qua, crab by Mallory Hawes, scallop by B Barrett, and skate by Örn Smári Gíslason. 


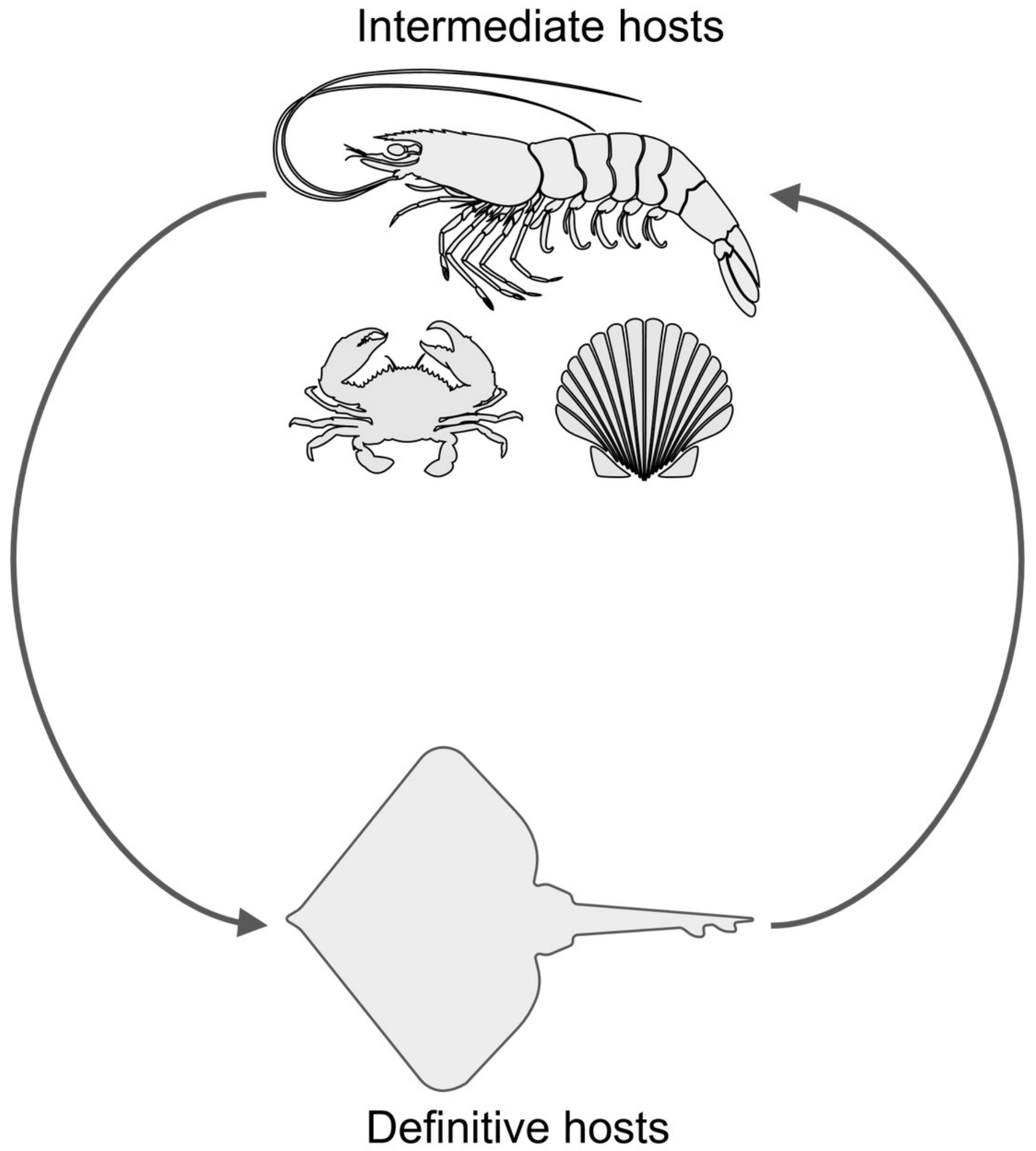




\section{Figure 3}

Infection patterns of sand crabs and mole crabs by parasites.

A) Infection of crabs by unidentified nematode species. Lepidopa benedicti data redrawn from Joseph \& Faulkes (2014). B) Infection pattern of crabs by Polypocephalus sp. larvae. Summary statistics: square $=$ mean; line dividing box $=$ median; box $=50 \%$ of data; whiskers $=95 \%$ of data; triangles $=$ minimum and maximum. Raw data shown by dots. 

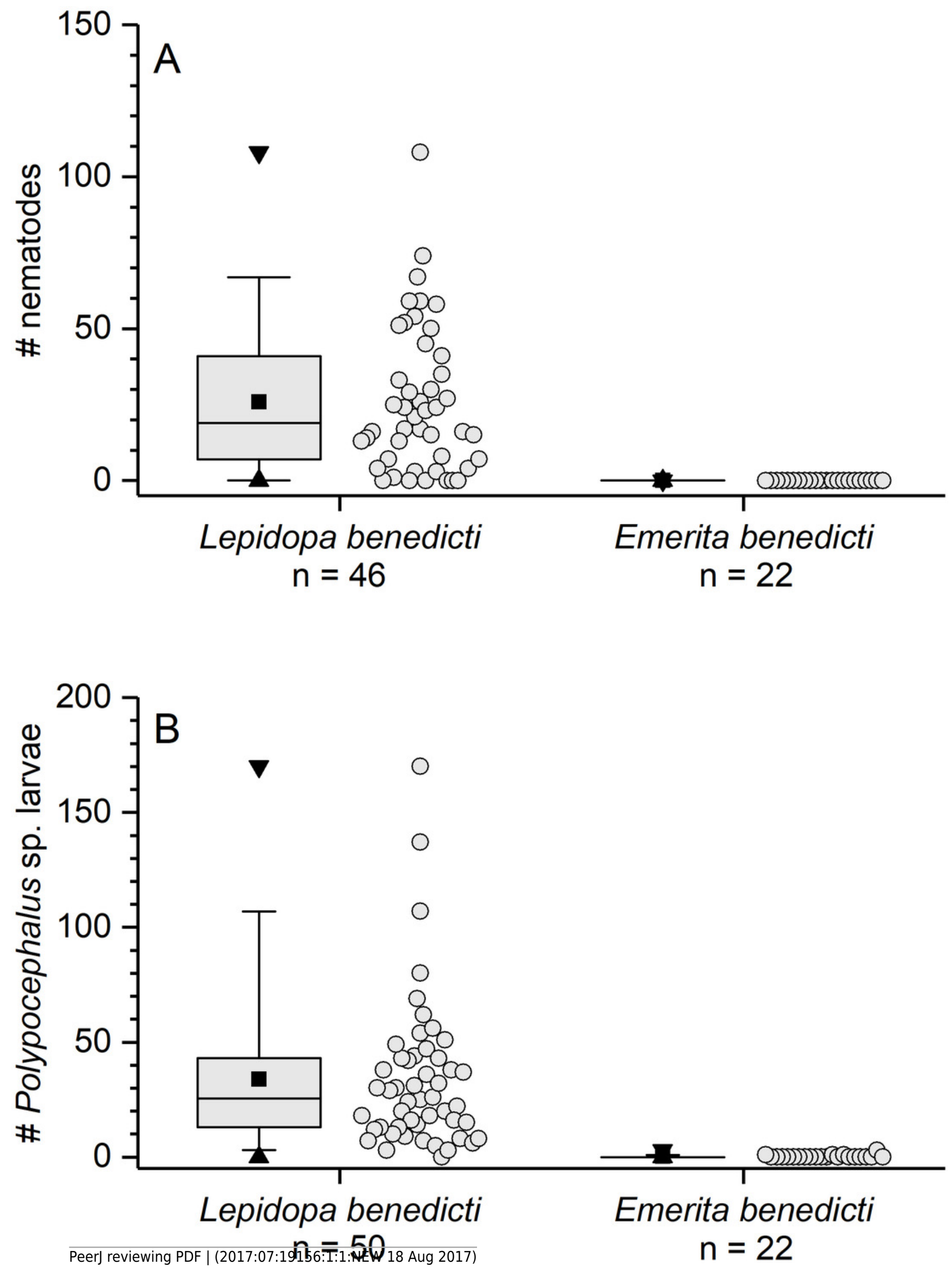


\section{Figure 4}

Micrographs of Polypocephalus sp. in nervous tissue.

A) Lepidopa benedicti thoracic ganglion 2. B) Lepidopa benedicti thoracic ganglia 3, and fused ganglion consisting of thoracic ganglia 4, 5, and abdominal ganglion 1. Different individual than A. C) Emerita benedicti brain. Arrow indicates single Polypocephalus larvae.

D. Emerita benedicti thoracic ganglion 1. No Polypocephalus sp. larvae in this individual. Different individual than C. Anterior towards top in A, and towards left in B-D.

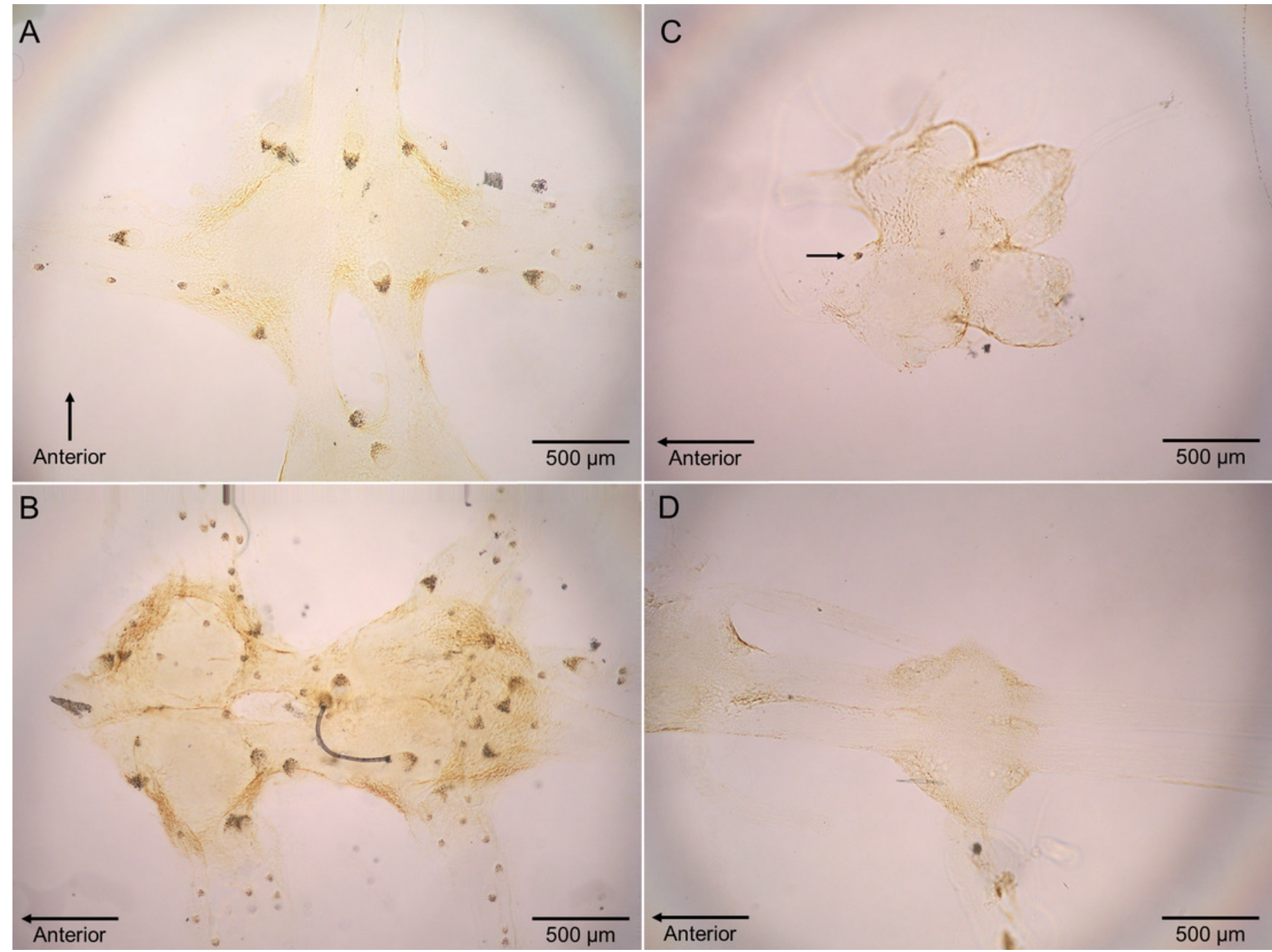


Figure 5

Bigger Lepidopa benedicti have more Polypocephalus sp. larvae.

Relationship between size of $L$. benedicti and intensity of Polypocephalus sp. infection.

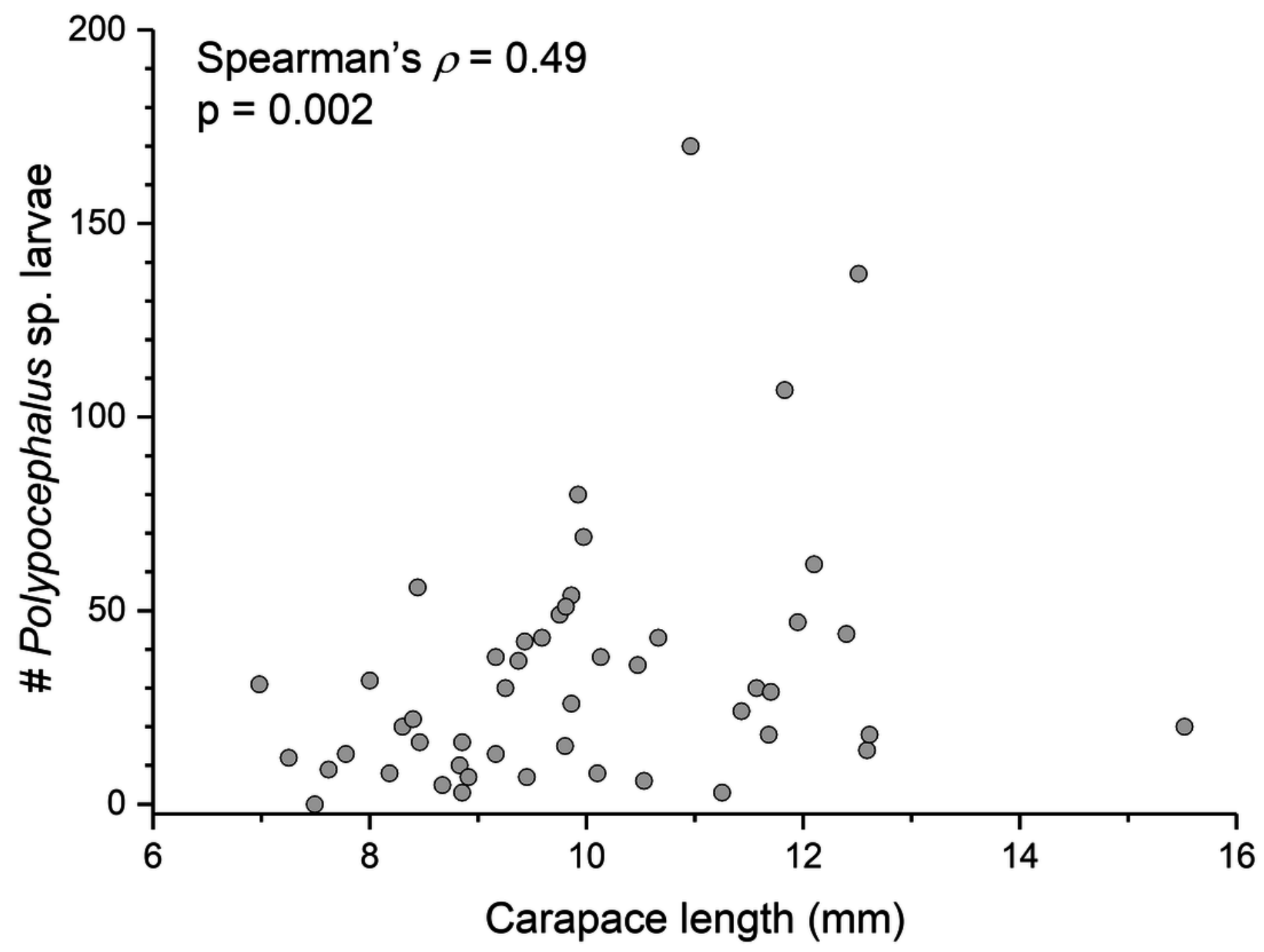


Figure 6

Number of Polypocephalus sp. larvae in different regions of the nerve cord in Lepidopa benedicti.

Summary statistics: square $=$ mean; line dividing box $=$ median; box $=50 \%$ of data;

whiskers $=95 \%$ of data; triangles $=$ minimum and maximum. Raw data shown by dots.

Groups sharing a letter do not differ significantly from each other. Sample sizes vary because some ganglia were damaged during dissection. SEG = subesophageal ganglion; $\mathrm{T}=$ thoracic ganglion; $A=$ abdominal ganglion.

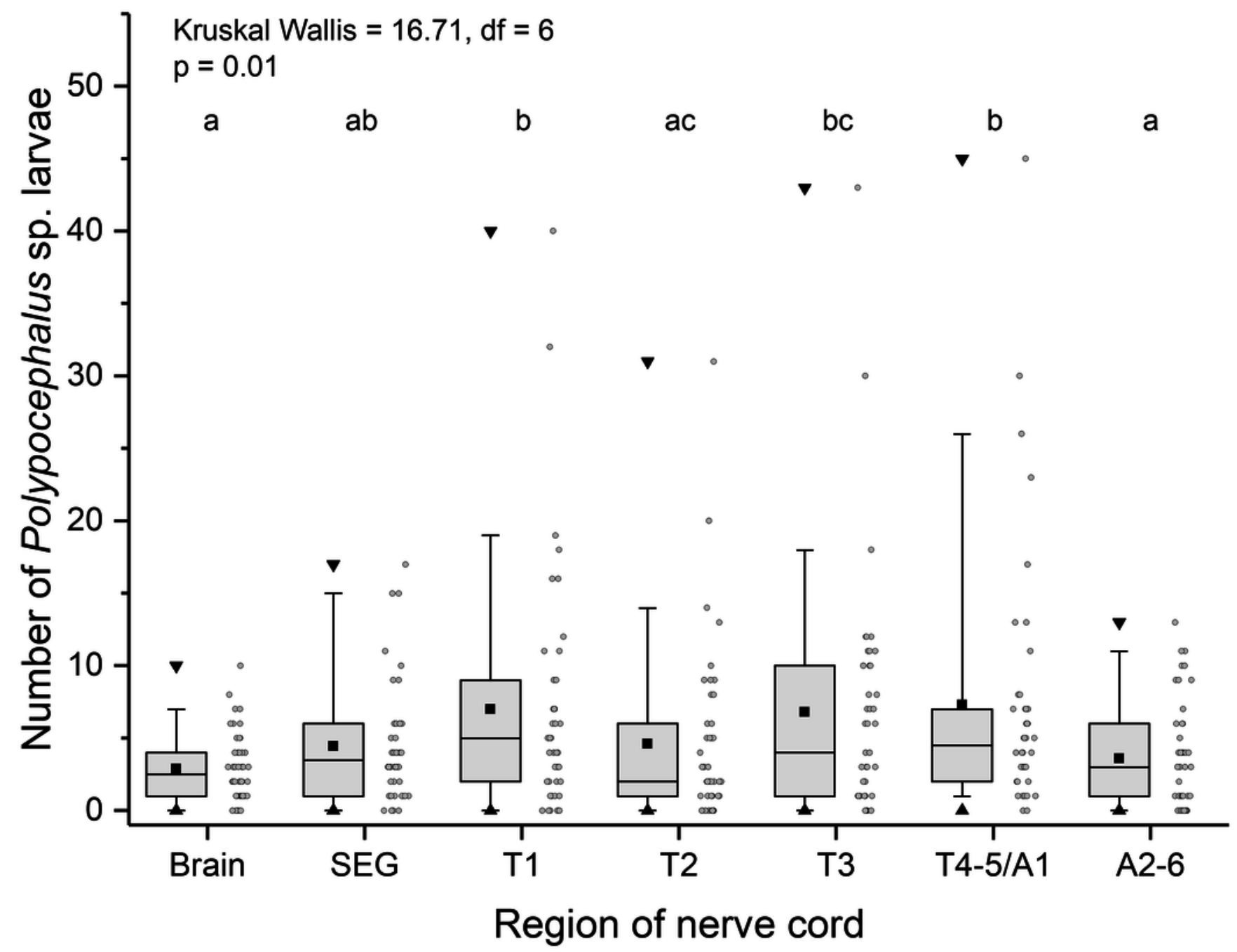


Figure 7

Polypocephalus sp. infection does not affect speed of digging in Lepidopa benedicti.

Relationship between intensity of Polypocephalus sp. infection and digging time in $L$. benedicti.

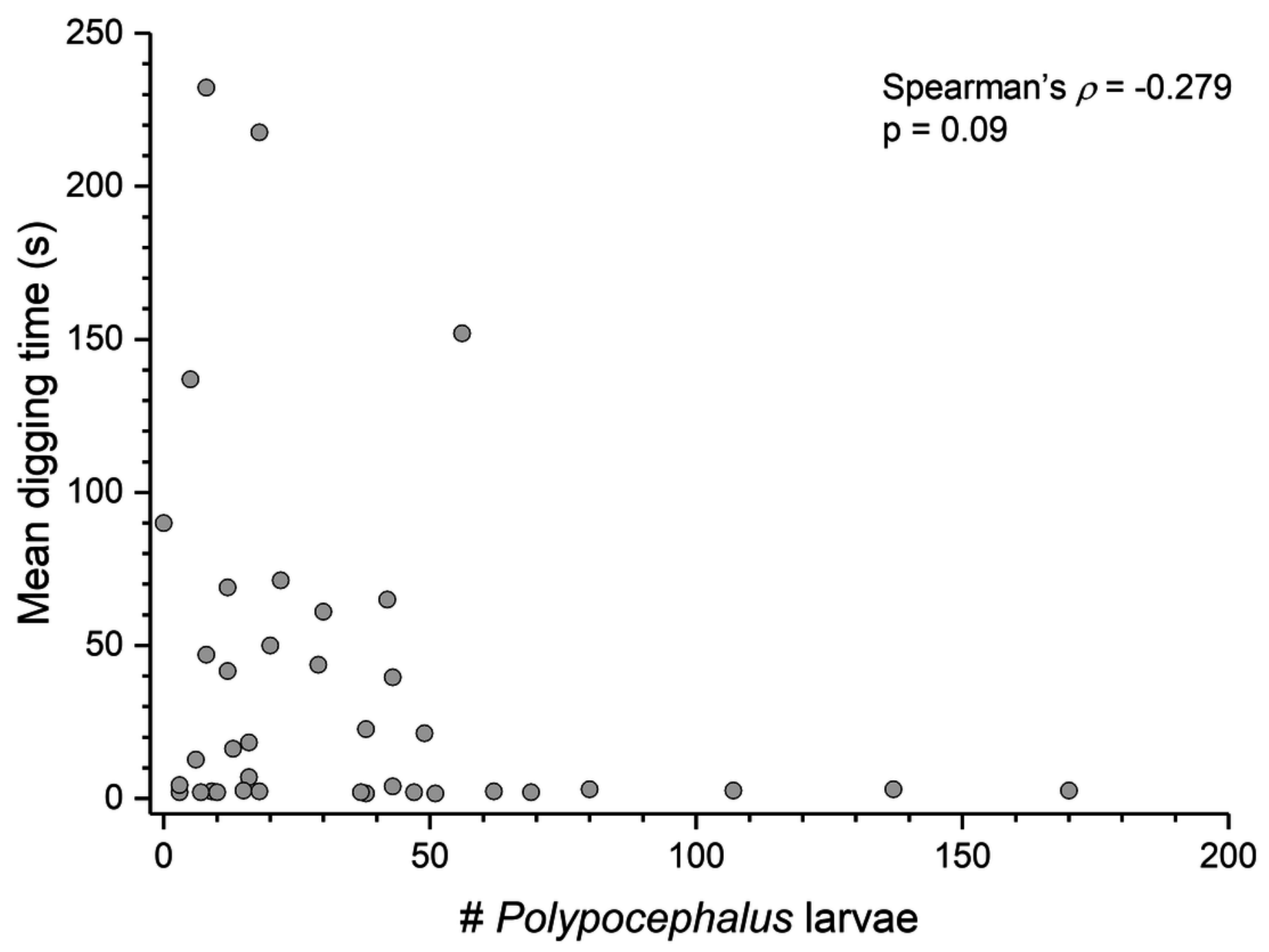


Figure 8

Size does not affect digging time in Lepidopa benedicti.

Relationship between carapace length and mean digging time in $L$. benedicti.

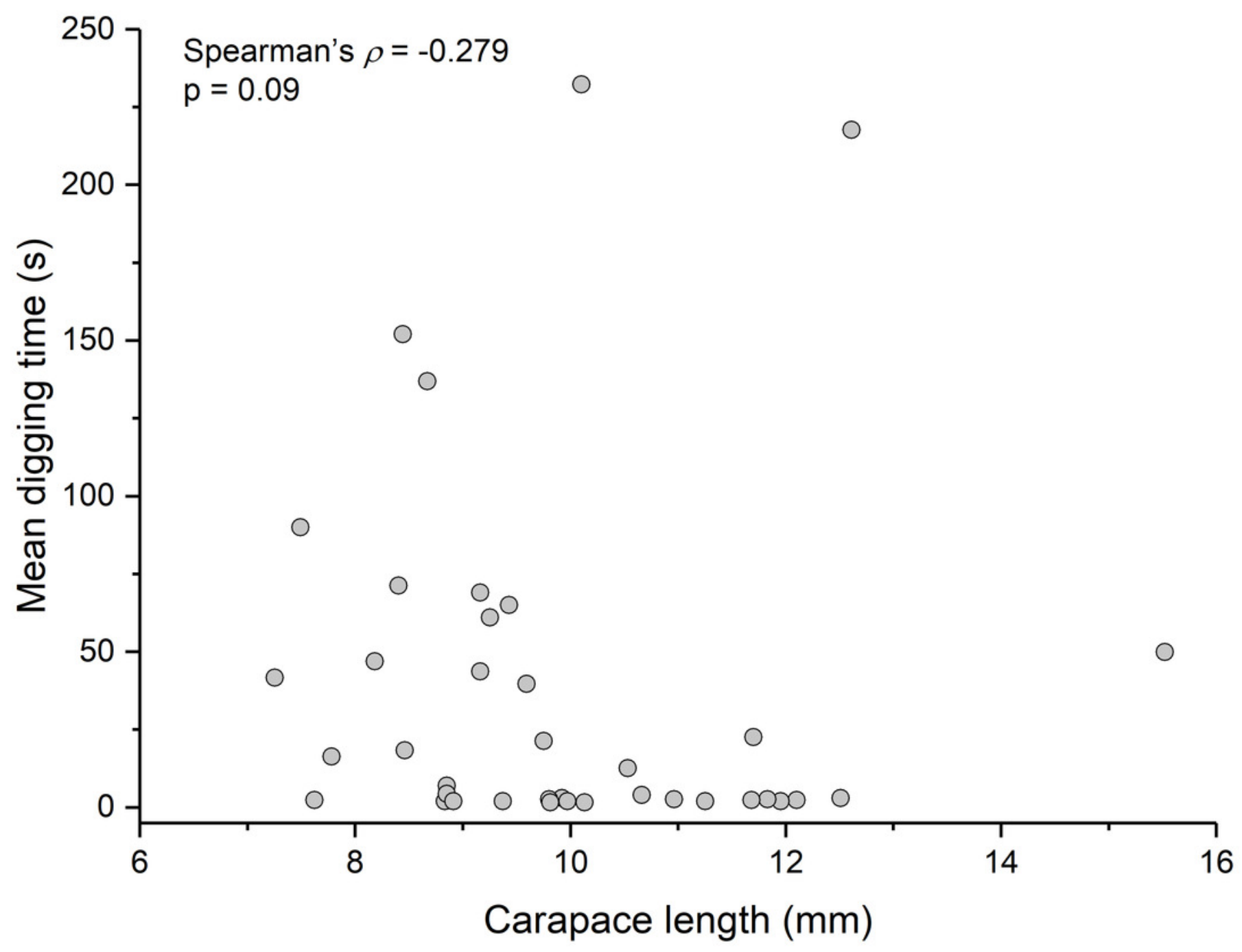


Figure 9

Time above sand for different behaviours by Lepidopa benedicti.

Duration of individual behaviour trials, grouped by different behaviours. $\mathrm{N}=110$ trials. Four trials involved combinations of sitting and swimming, and are not shown due to their rarity. Summary statistics: square $=$ mean; line dividing box $=$ median; box $=50 \%$ of data; whiskers $=95 \%$ of data; triangles $=$ minimum and maximum. Raw data shown by dots. Groups sharing a letter do not differ significantly from each other.

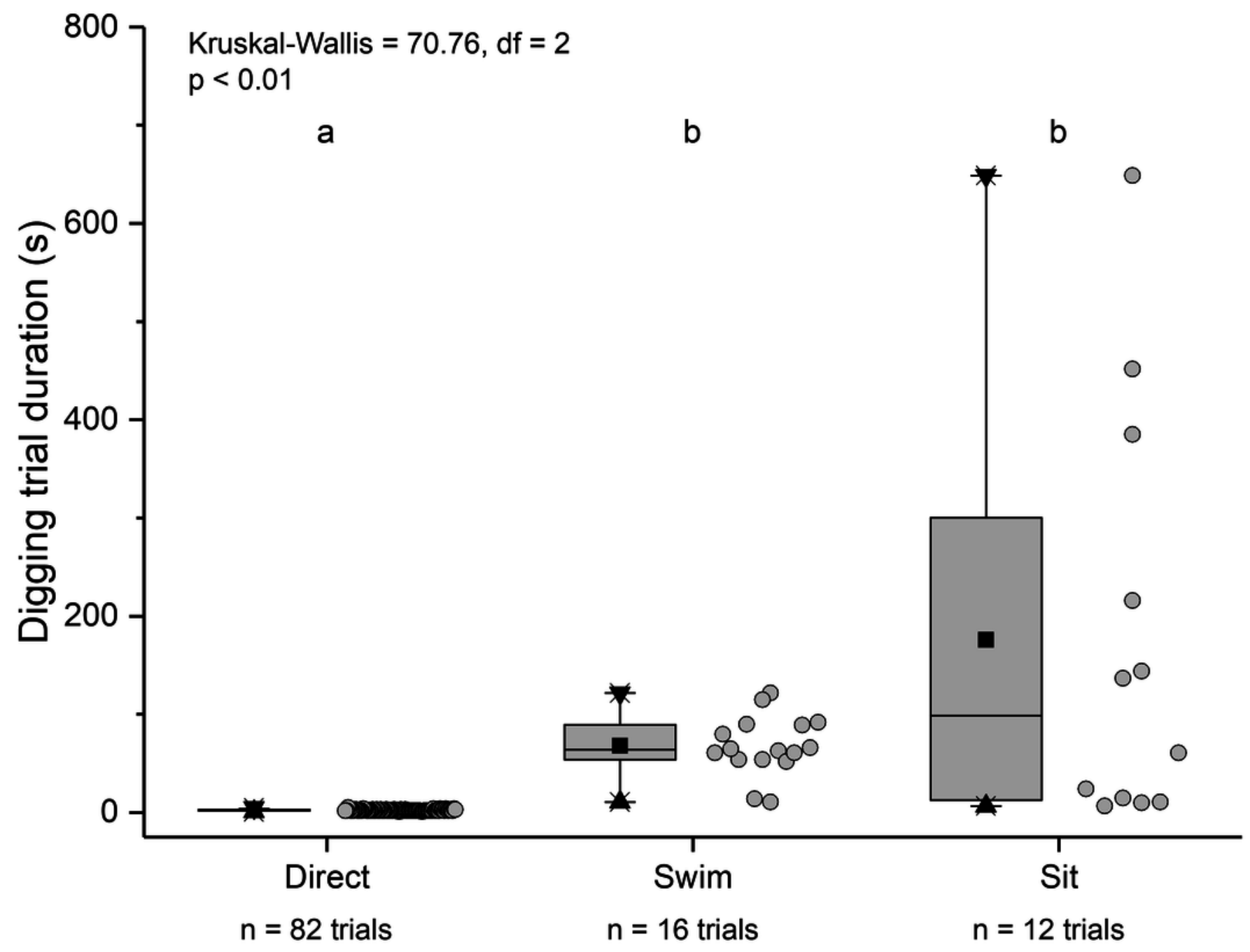




\section{Figure 10}

Infection intensity of Lepidopa benedicti individuals showing different behaviours.

Individuals categorized into three groups: those that always dug directly; those that swam at least once, but never "sat" (i.e., remaining immobile on the surface); those that "sat" at least once, but never swam. Summary statistics: square = mean; line dividing box = median; box $=50 \%$ of data; whiskers $=95 \%$ of data; triangles $=$ minimum and maximum. Raw data shown by dots. Groups sharing a letter do not differ significantly from each other.

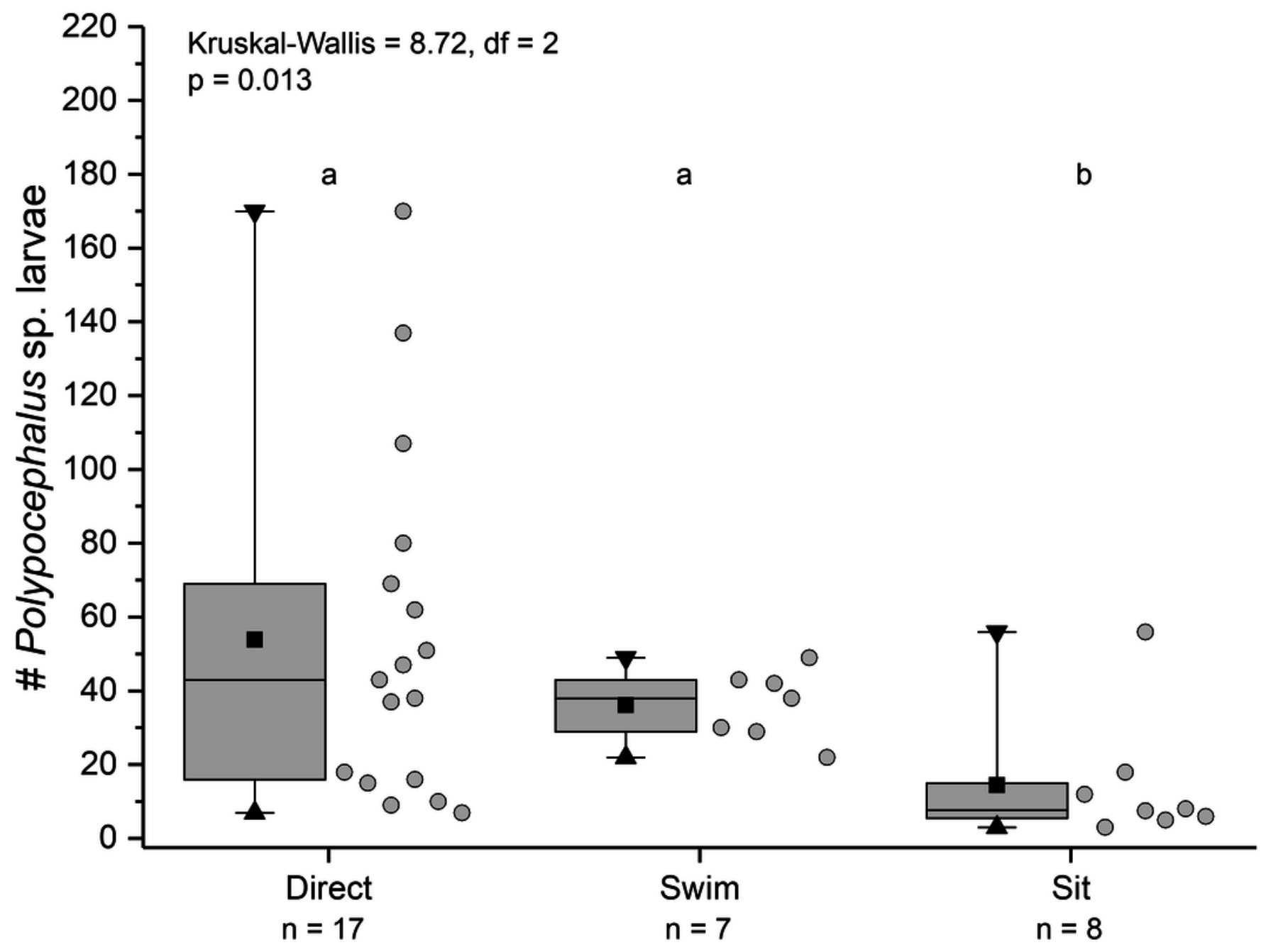

